\title{
THE TAXATION OF CANADA'S PETROLEUM INDUSTRY - REVISITED
}

\author{
N. J. STEWART*
}

Since the appearance of an article by the writer in this publication two years ago, ${ }^{1}$ taxpayers in Canada have been subjected to the buffetings of two federal budgets, both of which profoundly altered those provisions of the Income Tax Act ${ }^{2}$ particularly pertinent to the petroleum industry. As a consequence, many recent criticisms of Canadian income tax legislation are no longer relevant, but new problems have arisen to replace the old ones, and the never-ending battle continues.

The frequency of amendments to the provisions of the Income Tax Act which apply to the petroleum industry over the past decade has made any treatise upon the subject of only ephemeral validity at best, and therefore any comments upon this subject must be ventured with this fact constantly in the minds of the writer and reader alike. However, in the past two sessions, the Parliament of Canada has outdone itself in amending the tax law applicable to the petroleum industry, to such an extent indeed that the writer feels constrained to offer some comments by way of a sequel to the previous article. ${ }^{3}$ The tax picture there painted for the reader's mind has been knocked so far askew by these amendments that some attempt to set this picture straight again seems both desirable and necessary.

The amendments resulting from the 1962 federal budget, which were made effective after April 10th of that year, were almost entirely directed at the Canadian petroleum industry. The changes proposed by the federal budget of June 13,1963, as revised by the Minister of Finance on July 8,1962 , while not directed primarily at the petroleum industry, will nevertheless have a substantial effect upon it.

A philosophy completely new to Canadian income tax law was ushered into the Income Tax Act by the introduction in 1962 of new paragraph $(p)$ to subsection (1) of section 6." This new paragraph provides that there must be included, in computing the taxable income of a taxpayer, any amounts received by him in a taxation year as consideration for the disposition of a right, license or privilege to explore for, drill for or take petroleum or natural gas in Canada, if the disposition was made after April 10, 1962 pursuant to a contract or arrangement of the type to which new subsections $(5 \mathrm{~b})$ or $(5 \mathrm{c})$ of section $83 \mathrm{~A}$ would apply. Before even consulting the new subsections of section $83 \mathrm{~A}$, one is made aware by the language of new paragraph (p) alone that the proceeds from an outright sale of an interest in petroleum or natural gas rights for cash, which hitherto had been considered by most taxpayers as

- Nell J. Stewart of the Alberta Bar. Division Administrative Manager, Pan American Petroleum Corporation, Calgary, Alberta.

1 Stewart. Income Tax Law and Canada's Petroleum Industru (1962) 2 Alta. L. Rev. 18

2 R.S.C. 1952 c. 148, as amended by $1952-53$ c. 40, $1953-54$ c. 57.1955 cc. 54 and 53,1956 c 39,1957 c. $29,1957-58$ c. 17,1958 , c. 32,1959 c. 45,1960 c. $43,1960-61$ cc. 17 and 49 , and $1962-63$ c. 8.

4 By (Can.) 1962-63, c. 8 s. 1. 
a sale of a capital asset, notwithstanding the decision of the Income Tax Appeal Board in Great West Exploration Ltd. v. M.N.R.s would henceforth be taxable in the hands of the transferor. Thus a new day dawned.

The amendments to section 83A propounded the rest of the new income tax philosophy that applies to the petroleum industry. New subsections (4b) and (4c) were added" to section $83 \mathrm{~A}$ to permit companies not primarily engaged in the petroleum industry, and individuals, respectively, to deduct their expenses upon exploration and drilling in Canada, to the extent of their income from operating an oil or gas well in Canada, or from royalties on oil or gas well production in Canada. It is worthy of note that a corporation to which subsection (4b) applies, or an individual to whom subsection (4c) applies, may have difficulty with the provisions of new section $6(1)(p)$ which, as already noted above, treats any amount received as consideration for the sale of interests in petroleum and natural gas rights as income. Since this income is not income "from operating an oil or gas well in Canada", as required by new subsections (4b) and (4c), corporations or individuals affected by these two new subsections may find themselves taxable upon all the consideration paid to them upon disposing of petroleum and natural gas rights, even though they had incurred exploration and drilling expenses, because the present language of subsections (4b) and (4c) does not permit such deductions to be set off against such income. Nevertheless, subsections (4b) and (4c) were undoubtedly welcomed with open arms by a segment of the Canadian petroleum industry as a long overdue incentive which would attract new capital.

New subsections $(5 a)$ to $(5 e)^{7}$ inclusive of section $83 \mathrm{~A}$, are the pièces de résistance of the 1962 budget. Here we find the real fountainhead of the new tax philosophy developed in the 1962 amendments. Until April 10, 1962, taxpayers in Canada had complained that the allowance for the costs of acquiring interests in petroleum and natural gas rights, as contained in subsection (6) of section $83 \mathrm{~A}$, was inadequate and unduly restrictive, since only payments by way of consideration paid directly to the government of Canada or to a province could be deducted, and then only if the petroleum rights had been surrendered to the Crown and "... without receiving any consideration therefor or repayment of any part of the amount so paid ...", and before any production had been recovered in reasonable commercial quantities. On the other hand, taxpayers who receive payments upon the transfer of their entire interests in petroleum rights to other parties rather relished the notion that such receipts were on capital account and therefore non-taxable. But this proved rather evanescent in the Great West Exploration case ${ }^{8}$ and in other decisions as well, including the McMahon and Burns case. ${ }^{9}$

Subsection (5a) of section 83A clearly established, for the first time in Canadian tax law, that an amount paid under an agreement for a right, license or privilege to explore or drill for oil and gas in Canada after April 10, 1962 would be deemed to be a drilling or exploration expense which is deductible in the current or any subsequent year by the taxpayer.

6 (1957) 17 Tax A.B.C. 416

(Can.) 1962-63 c. 8 \&. 19(7).

7 totd.

M MeMahon \& Burms Ltd. v. M.N.R. [1958] C.T.C. 153. 
Since the deduction allowed is limited to expenditures made for a right ". . . to enter upon, use and occupy so much of the land as may be necessary for exploiting such right, ..." outright purchases of title to mines and minerals, or of title to the surface of the land together with title to the mines and minerals, are excluded from the deduction. Although the costs of acquiring any working interest would seemingly qualify for a deduction under subsection (5a), it is doubtful that the costs of acquiring an overriding royalty, a carried interest or a net profits interest would qualify unless the party acquiring such an interest enjoyed the right to explore for, drill for or take petroleum substances within the lands in question under the agreement, which is usually not the case. As this subsection now reads, the words "explore for, drill for or take . . . petroleum ..." may be read disjunctively, in which case many more taxpayers will benefit from the deduction allowed thereunder than would be the case if these expressions are read conjunctively, obliging taxpayers to secure all of these rights to themselves or suffer the loss of the deduction for the costs of acquiring the interest in question. As to which of these interpretations will prevail, the writer suspects no one knows at present.

Since the deduction under subsection (5a) applies to acquisitions of ". . petroleum, natural gas or other related hydrocarbons (except coal) ...", perhaps no deduction would be allowed for the consideration paid (or deemed to have been paid in an omnibus acquisition of an interest in mines and minerals) for such substances as sulphur, helium or so-called hard minerals, which are not "related hydrocarbons". It would appear, in the light of the amendments to subsection (5) in 1962, that it is intended that payments of the type usually characterized as "delay rental payments" which are agreed upon in the agreement by which the petroleum rights are acquired, may also be deducted under new subsection (5a), but this is not a certainty under the present language of this subsection.

Without turning our backs on the position of the transferee under new subsection (5a), let us pass on for the moment to new subsection (5b) of section 83A to see what happens to the transferor of a petroleum interest under this new tax philosophy. The scriptures have long taught us that "The Lord giveth and He taketh away", so we should not be surprised after recognizing the beneficence granted by subsection (5a) that there is a price to be paid for it, and this price is largely spelled out in new subsection (5b). The latter subsection states that if a company qualifying as an oil or gas company disposes of a petroleum right similar to that described in subsection (5a) after April 10, 1962, any amount received by the transferor as consideration for such disposition must be considered taxable income in the year of receipt. Excepted from these provisions are dispositions pursuant to an inheritance or bequest for obvious reasons, and dispositions made between April 11, 1962 and November 9, 1962 during which period a moratorium existed in respect of the new provisions, in order to deal fairly with certain taxpayers who were in the midst of mergers, amalgamations or reorganizations when the 1962 budget was first presented in April but which were consummated before the new provisions were publicized and became law in their final form in November of 1962. 
The language of subsection (5b) does not characterize the sum deemed to be income thereunder as drilling or exploration income, although the payer of the sum referred to in subsection (5b) must treat such payment as a drilling or exploration expense. Perhaps this is because the exploration and drilling phases of the petroleum industry do not of themselves generate income, any more than the erection of a factory by itself might generate income. It is the sale of production recovered from the holes drilled, or the sale of products manufactured in the factory erected that, in the true sense, produce income. However, characterizing the income which is deemed by subsection (5b) to have been received by the transferor of a petroleum interest is both necessary and difficult. If it is viewed as of the same character as income from the sale of petroleum products, it is depletable, but if not of the same character, then the depletion allowance will not apply to such income and it will have to be segregated by each taxpayer from other income from the sale of petroleum products in determining taxable income.

Since subsection (5b) of section $83 \mathrm{~A}$ does not state that the consideration for the sale of a petroleum and natural gas interest is deemed to be income from an oil or gas well in Canada, income that is subject to depletion may be converted into income which is not subject to this allowance. This result follows from the application of subsection (5a), which rules that the costs of acquiring petroleum and natural gas rights are deemed to be drilling and exploration expenses and must perforce be deducted from the profits from the sale of petroleum substances in computing the depletion allowed to any taxpayer. For example, let us assume that $A$ has net production income of $\$ 50,000.00$ from certain petroleum leases which he later sells outright to $B$ for $\$ 50,000.00$. A then acquires other petroleum leases in the same area from $C$, again for $\$ 50,000.00$. The expenditure made by $A$ to $C$ would reduce the income from the sale of production to nil, and therefore the $\$ 50,000.00$ received by $A$ from $B$ would be taxable as ordinary income without any allowance for depletion. Any time a taxpayer receives income from the sale of petroleum or natural gas interests which exceeds such taxpayer's accumulated exploration and development expenses, the excess is taxable at full rates without reduction by the depletion allowance.

Another feature of subsection (5b), which is also common to subsection (5c) of section $83 \mathrm{~A}$, deserves some comment. Few would blanch at the prospect of a tax pursuant to one or the other of these subsections upon the profit only from such dispositions, but the tax imposed thereunder is levied against the entire proceeds of any such disposition, even though the interest being disposed of may have been acquired before any deduction was granted for the costs of such acquisition, other than that allowed under subsection (6) of section 83A. The fiscus apparently justifies the violence done to the taxpayer by subsections (5b) and (5c) in this manner by stating that the new approach has to commence from a fixed date, and deductions cannot be permitted for costs incurred before that date without opening the door to an allowance of ex post facto deductions for all kinds of costs for which no deduction was allowed under the law when these costs were incurred. 
New subsection (5c) of section $83 \mathrm{~A}$ is almost a parallel to subsection (5b), but it is directed at individuals and companies other than those principally engaged in the petroleum business. However, it has one difference which can be significant in certain circumstances. Whereas subsection (5b) includes in income the proceeds from any disposition of a petroleum or natural gas interest made after April 10, 1962, no matter when acquired, subsection (5c) includes in income the proceeds from any similar disposition only if the interest being disposed of was acquired after April 10, 1962. Thus an interest in petroleum substances acquired before that date may be disposed of by an individual, or by a company other than one of the type referred to in subsection (5b), without tax upon the proceeds of the disposition. This feature may prove to be distinctly beneficial to the very few taxpayers who are able to take advantage of it.

The difficulties of employing production payment financing in Canada prior to the 1962 amendments to the Income Tax Act, were discussed in the earlier article in this publication. ${ }^{10}$ It has been suggested by some that new subsections (5a) to (5e) inclusive of section $83 \mathrm{~A}$ are of such broad effect as to make production payment financing feasible in Canada now.'1 According to these suggestions, investor $X$ could invest $\$ 1,000,000$ in a petroleum and natural gas property and claim that this investment was an expense under subsection (5a) in the years during which the investment is being recovered. If it should require ten years to recover this investment, $X$ will have received $\$ 1,000,000$ plus interest at the end of the tenth year, but the interest is taxable in the last year only. Furthermore, $X$ could claim depletion under Regulation $1202^{12}$ upon the interest portion of the payments which he receives out of production from an oil or gas well, whereas in the United States where cost depletion has long existed and where production payments are extremely common means of financing petroleum and natural gas ventures, the interest portion of any payment is subject to taxation at ordinary rates, without reduction by depletion. Presumably, those advocating such an arrangement assume that the interest portion, and only the interest portion, of the payments received from the sale of production would attract a tax in Canada, pursuant to the new amendments.

It is not at all certain that the millenium of production payment financing has arrived yet in Canada through the introduction of new subsections (5a) to (5e) inclusive of section $83 \mathrm{~A}$. The keystone of the arch of production payment financing is a right in the purchaser of such a payment to deduct or otherwise recover free of tax the costs of acquiring such payment by some means which is recognized and approved by the tax gatherer. Let us return for a moment to subsection (5a), which the reader was admonished to keep in mind as he examines the remaining new subsections of section 83A. A deduction for the costs of acquiring a petroleum interest is available only if the taxpayer acquires, pursuant to a contract or arrangement, the right to ". . explore for, drill for or take

10 n. 1, supra

11 Burton, 1962 Canadian Income Tares Affecting the Canadian Oil and Gas Industry. [1863] Prentice-Hall Oll and Gas Taxes 4441, 4442.

12 Income Tax Regulatlons (Can.) P.C. 1954-1917 S.O.R. /54-682 (dated 8 Dec. 1954, Dub. 12 Jan. 1955), am. P.C. 1961-24 S.0.R. 61-62 (pub. 25 Jan. 1961). 
petroleum, natural gas or other related hydrocarbons . . ." in Canada after April 10, 1962, and he must not acquire any right by such contract other than a right in respect of the land in question to "... enter upon, use and occupy so much of the land as may be necessary for the purpose of exploiting such right, ..." It is extremely doubtful that the Department of National Revenue would agree that the purchaser of a production payment under the well known "ABC" transaction acquires a right to enter upon and occupy the lands in question for the purpose of exploring for or drilling for petroleum or natural gas. Instead, such purchaser really buys a debt which is payable to him out of the production of petroleum substances and in ordinary circumstances he has nothing to do with the exploration for or the drilling for petroleum substances within or upon the lands subject to the production payment, because these activities are undertaken by parties other than the owner of the production payment. A fortiori, if the purchaser of an "ABC" production payment cannot reasonably expect a deduction for his cost of acquisition, or a means of recovering these costs free of tax, the keystone of our arch is thereby removed and the whole arch tumbles in ruins.

Another nail is driven into the coffin of "ABC" production payment transactions through the introduction of new subsection (5b). $A$, the original owner of the property in question who might hitherto have hoped to have his disposition of the working interest to $\mathbf{C}$ and his disposition of the reserved production payment to $B$ both treated as capital gains, has had any such hopes completely dashed because subsection (5b) clearly characterizes the receipts from such dispositions as income to $\mathrm{A}$.

Notwithstanding the foregoing, it now seems possible for a "carvedout" production payment to be utilized to advantage in Canada, so long as the party who purchases the payment also obtains the right to enter upon the lands subject to the payment for the purpose of conducting operations thereon, and the right to take the production in kind that accrues to him in satisfaction of the production payment. Assuming that the various qualifications for a deduction under subsection (5a) of section $83 \mathrm{~A}$ are to be read disjunctively, as mentioned earlier, the "carved-out" production payment may become a commonplace in Canada.

New subsection (5d) ${ }^{13}$ of section $83 \mathrm{~A}$ states that if a right, license or privilege of the type described in subsections (5a) or (5b) is acquired after April 10, 1962, by an association, partnership, syndicate or corporation, or by an individual, as the case may be, under an agreement, contract or arrangement of a type other than as described in subsection (5a), the party making the disposition is not taxed upon the proceeds of the disposition under subsections (5b) or (5c). Venturesome taxpayers may wish to seize upon the language of subsection (5d) to support an argument that any disposition pursuant to a contract dated prior to April 10, 1962, (the date mentioned in subsection (5a) as the effective date of the subsection) is free of tax. A more likely and safer interpretation of subsection (5d) is that any disposition of petroleum rights pursuant to a contract which also disposes of other rights in the lands in question (e.g. an outright sale of the entire fee simple estate), if made

13 n. 6, supre. 
after April 10, 1962, would be free of tax under subsections (5b) and (5c). Some clarification of the intended meaning of the language of subsection (5d) can probably be expected in forthcoming amendments to section 83A.

Subsection (5e) provides that if a taxpayer disposes of an interest in land which includes a right, license or privilege of the type described in subsection (5a) in addition to other rights, the entire proceeds from such disposition are deemed to be income from the sale of the right, license or privilege. Concurrently, under this new subsection, if a taxpayer who has acquired a right, license or privilege of the type described in subsection (5a) disposes of a portion only of the interest so acquired, the proceeds from such disposition are deemed to be income nevertheless. Subsection (5e) obliges the taxpayer to accept the same tax treatment of a particular disposition of a petroleum interest, whether such disposition is accomplished in one fell swoop, or piecemeal by a series of unrelated sales. This seems to be a necessary safeguard if the principle of taxing such transactions is to be fairly and equitably applied.

However, there are other hazards contained in subsection (5e) that are much less acceptable and which were probably never intended when the amendments were passed into law. As mentioned earlier in this paper, any amount paid for an overriding royality, a carried interest or a net profits interest is apparently non-deductible as an exploration or drilling expense under the provisions of subsection (5a), even as the consideration paid for the exotic $\mathrm{ABC}$ production payment appears to be non-deductible. However, under subsection (5e) it would appear that any amounts received from the disposition of any such interests are considered to be the proceeds of disposition of a right, license or privilege, and are therefore taxable. Rather clearly, some relief is necessary soon if the ordinary garden variety of overriding royalty interest, carried interest or net profits interest is to survive in Canada.

There are a number of other problems which have arisen out of new subsections (5a) to (5e) inclusive of section $83 \mathrm{~A}$, to which reference has not yet been made. For instance, when subsection (5b) first appeared, some taxpayers concluded that its provisions would impose a tax upon the exchanges of petroleum interests affected between oil companies in day-to-day farmout agreements, which, if true, would be a most serious consequence to the entire petroleum industry. The lamentations of those holding this belief wrung the hearts of certain members of Parliament; so much so that a question was asked in the House of Commons on November 18, 1962 in connection therewith and a statement was made to the effect that since the farmor in a typical farmout arrangement does not actually receive any payment for the interest which he assigns, but rather receives some development or drilling work thereon, there is therefore no amount to be brought into income, and subsection (5b) would not impose a tax upon such a transaction:" This assurance provided considerable relief to many disquieted taxpayers, although the extent to which the Department of National Revenue may feel bound by a statement made in the House of Commons in answer to a question from the floor is certainly an open

14 See remarks of Mr. Smith and Mr. Grafftey, (Can. 1962) 107 H.C. Deb. no. 36, 177, 1723. 
question. It is submitted that subsection (5b) of section $83 \mathrm{~A}$, by its own terms, gives the taxpayer ample assurances that a farmout type of transaction would not be taxed thereunder. The owner of a petroleum interest, in offering a portion of such interest to another party in return for the other party's covenant to explore upon or develop the lands in question, it is submitted, does not thereby "dispose of" a right, license or privilege to explore for, drill for or take petroleum in Canada, within the meaning of subsection ( $5 \mathrm{~b}$ ) because he still retains various rights to the petroleum interest subject to the farmout. Ordinarily, a farmout agreement simply provides for a sharing of the economic burden of conducting exploration operations, and even further, if we assume two parties dealing with each other bona fide and at arm's length in a farmout, if a tax were to be imposed under subsection (5b), it would have to be determined which party has the best of the bargain and the extent to which such party has bested his opponent or opponents in order to establish the "amount received" within the meaning of subsection (5b). The determination of an "amount received" through the making of a farmout is impossible and absurd in the typical farmout arrangement because it cannot be established, except in the rarest of circumstances, whether the bargain made by the "farmor" is provident or improvident in the taxation year in which the farmout is made. It would therefore seem that subsection (5b) cannot logically be stretched to fit the farmout arrangements which are the daily bread and butter of the petroleum industry.

An amendment to the provisions of subsection (8a) of section 83A, which was assented to on November 29th, 1962 and made applicable to the 1962 and subsequent taxation years, ${ }^{15}$ has removed most of the difficulties of complying with this subsection in the course of reorganizing one oil company into another. It will be remembered that under the law applicable to the taxation years 1954 to 1961 inclusive, the predecessor company was obliged to dispose of all or substantially all of its assets to the successor company, either in return for shares of the capital stock of the successor company, or as a result of the distribution of the property of the predecessor company to the successor company upon the winding up of the predecessor company after the necessary share exchanges between the predecessor and the successor companies had taken place. Only by close adherence to this tortuous course could credits against Canadian income taxes accumulated in the name of the predecessor company be secured to the benefit of the successor company through the reorganization. The corporate gymnastics required by subsection (8a) were such that only a very few corporate taxpayers were fortunate enough to have corporate organizations which lent themselves to a possible reorganization in the pattern required; and this quite apart from the difficulties of matching the share exchanges which would be acceptable to the parties to a proposed reorganization for business reasons with the share exchanges necessary under this subsection, if the credits against income taxes accumulated by the predecessor company were to survive the reorganization. 
The repealing of paragraphs (c), (d) and (da) of subsection (8a) in $1962^{16}$ permits the parties to a proposed reorganization to transfer the Canadian assets of the predecessor company to the successor company without undertaking the complicated and often unnecessary and undesirable exchange of shares of capital stock, while still preserving the credits against income tax accumulated by the predecessor company for the benefit of the successor company. Such a simplified arrangement will undoubtedly be of much wider benefit to the petroleum industry than the earlier arrangements under subsection (8a), without in any way encouraging a traffic in credits against Canadian income taxes, against which the Department has quite justifiably set itself.

Some reorganizations among oil companies which achieved wide publicity in 1962 have still not been fully consummated in accordance with the desires of the parties involved, for reasons other than the impact of subsection (8a). Various of these reorganizations which became the topic of the day almost certainly had as their ultimate objectives the winding up and disappearance of the predecessor company involved therewith, in order to simplify corporate organizations. Whereas these ambitions will probably be fulfilled some day in any event, the imposition of a tax upon the value of the assets disposed of by the predecessor company under new subsections (5b) or (5c) of section 83A has enforced a continuation in existence of the predecessor company in these transactions as title holders of the assets in question, if a prohibitive income tax is to be avoided.

Both of the last two federal governments have indicated their strong disapproval of a continued attrition which would ultimately denude Canada of Canadian companies in the extractive industries. This disapproval has been manifested through the imposition of a tax upon the proceeds from the disposition of petroleum interests, and more recently through the ill-fated proposal of the present federal government to impose a punitive tax upon the sale of securities in amounts which would or could transfer control of a Canadian company to foreign ownership. The preservation of Canadian-controlled companies which are active in the extraction of Canada's natural resources is a subject involving extremely far-reaching political, social and economic considerations which are quite outside the scope of this article or any other article dealing with the law as we find it. Perhaps one might observe, however, in a context which is admittedly partly outside purely legal considerations, that whereas the present tax law in Canada has prevented the complete disappearance of certain Canadian oil companies which became involved with reorganizations with companies controlled outside of Canada, the continued existence of these erstwhile Canadian companies as unnecessary and unwanted appendages upon the corporate organizations which now own and control them makes no contribution whatever toward a realization of the aims of Canadian parliamentarians. The sham of forcing a continuation in existence of these companies as Canadian entities is hardly worthy of any country boasting a strong legal heritage.

The present federal government has also gone on record as opposing any amendments to the Income Tax Act which would permit anyone to

10 id. s. $19(11)$ 
deduct exploration expenses from income from any source whatever. Such an allowance has been dear to the hearts of some taxpayers in Canada for many years. In answer to a question on this point, the present Minister of Finance pronounced his government ill-disposed toward the creation of ". . . a class of Texas millionaires in Canada, as has happened in the United States ..." The Minister stated that under such an arrangement, persons in the top income brackets ". . . can by gambling 20 per cent of their own money and 80 per cent of the government's money ..." make a fortune if they are lucky or lose only 20 per cent of their money if they are unlucky. "So far as this government is concerned it is against that kind of discrimination in favour of the rich".17 And so die, at least for the present, the hopes of those who believe that a broadening of the rights to deduct exploration and development expenses would generate considerably more investment by Canadians in the Canadian petroleum industry.

With the passing into law of the rather radical changes to the Income Tax Act which the last two parliaments have enacted, perhaps we can look forward to a period of relative tranquillity, during which amendments to the provisions of the Act bearing upon the petroleum industry will be of a minor nature, directed towards the clarification of existing tax principles, rather than the propounding of new tax philosophies. There can be no doubt that some peace and quiet respecting income tax legislation is much to be desired and is perhaps long overdue in Canada particularly as regards the petroleum industry, if that stability in the law which is so necessary to the continued growth of any competitive industry is to be assured. 